\title{
THE EFFECT OF AEROBIC EXERCISES ON BLOOD GLUCOSE CONCENTRATION IN HEALTHY GIRLS AND GIRLS WITH TYPE 1 DIABETES MELLITUS
}

\author{
Sandrija Sideravičiūtė, Alina Gailiūnienė, Kristina Visagurskienė, Daiva Vizbaraitė \\ Lithuanian Academy of Physical Education, Kaunas, Lithuania
}

Sandrija Sideravičiūtė. Doctor of Biomedical Sciences. Lector of Department of Applied Physiology and Health Education at the Lithuania Academy of Physical Education. The field of scientific research — the research of youth's functional and morfological health indexes.

\begin{abstract}
Regular aerobic exercises are beneficial not only for healthy people. Physical activity plays a big part in the lives of children and adolescents with type 1 diabetes mellitus too. Walking, biking, swimming, dancing, and many other activities are considered to be aerobic exercises and they are all healthy. What kind of physical exercises are the most useful for the youth with type 1 diabetes mellitus?

So, the aim of the present study was to estimate and compare the effect of aerobic exercise such as swimming and aerobics, on blood glucose concentration of young girls. 19 girls aged $16.5 \pm 0.24$ years with the duration of diabetes for $8.1 \pm 0.9$ years and 28 healthy girls aged $16.9 \pm 0.36$ years participated in the study.

Two experiments were carried out. The first experiment was a 7-day physical exercise program, consisting of aerobics and swimming training sessions each day. The other experiment was a 14-week swimming program, where all the participants attended swimming training sessions two times per week, and there were all in all 28 training sessions. Glycemia control was assessed by blood glucose level (mmol / l) monitored before and after every training sessions during the 7-day and 14-week physical programs.

After the analysis of blood test it was found, that the 7-day physical program decreased blood glucose concentration for all subjects $(p<0.05)$ but, swimming had a greater effect on blood glucose control for girls with type 1 diabetes mellitus than aerobics $(p<0.01)$. After the 14-week duration swimming program, hyperglycemia significantly decreased for all subjects too, but it's response to the regular physical activity in the water was the highest for diabetics $(p<0.001)$.

The evidence obtained in this study showed that both swimming and aerobics decreased blood glucose concentration for healthy subject and for subjects with diabetes. But swimming had a greater effect on the dynamics of blood glucose level for girls with type 1 diabetes mellitus than aerobics.
\end{abstract}

Keywords: type 1 diabetes mellitus, swimming, aerobics, blood glucose, glycemia.

\section{INTRODUCTION}

Diabetes mellitus metabolic syndrome consisting of two main groups, type 1 and 2, is characterized by absolute or relative insulin deficiency or insulin resistance (Bhaskarabhatla, Birrer, 2005). The major modes of treatment for diabetes are insulin administration, diet and exercises (Wilmore, David, 1999). Individuals with diabetes mellitus take part in physical activity for health promotion, disease management, and recreational or competitive sports (Bhaskarabhatla, Birrer, 2005). The role of regular exercise and physical training in improving glycemic control (regulation of blood sugar levels) in patients with type 1 diabetes has not been clearly defined and is controversial (Wilmore, David, 1999). In people with type 1 diabetes, glycemic control might or might not be improved with exercise. But there are other potential benefits of exercises for these patients (Wilmore, David, 1999). The benefits derived from regular physical activity include improved cardiovascu- 
lar fitness, increased lean mass, improved blood lipid profile, enhanced psychosocial well-being, lowered blood glucose, and decreased body adiposity (Bernardini et al., 2004; Defrin et al., 2004; The Diabetes Research in Children Network (DirecNet) Study Group, 2006; Riddell, Iscoe, 2006). Exercise plays a big part in the lives of children and teens with type 1 diabetes too (The Diabetes Research in Children Network (DirecNet) Study Group, 2006). We wanted to study the effects of aerobic exercise on glucose concentration in adolescents with type 1 diabetes mellitus. Aerobic exercise is a type of exercise that works the heart and lungs for an extended period of time. Walking, biking, swimming, jogging, dancing, jump-roping, and many other activities are considered aerobic exercise (The Diabetes Research in Children Network (DirecNet) Study Group, 2006). Thus, the aim of this study was to estimate and to compare the effect of such aerobic exercise like swimming and aerobics on blood glucose concentration in adolescent girls with type 1 diabetes mellitus.

\section{METHODS}

Subjects. 19 girls aged $16.5 \pm 0.24$ years with the duration of diabetes for $8.1 \pm 0.9$ years and 28 healthy girls aged $16.9 \pm 0.36$ years participated in the study. None of the subjects was specializing in any form of sports training.

Anthropometric measurements. All the subjects were measured: 1 . for their height $(\mathrm{cm})-$ standing height was measured without shoes to the nearest $0.5 \mathrm{~cm}$ with use of the stadiometer, keeping the shoulders in a relaxed position and the arms hanging freely (Lohman et al., 1991); 2 . body mass $(\mathrm{kg})$ - standing weight was measured without shoes in the minimum clothing possible. Body mass index - BMI $\left(\mathrm{kg} / \mathrm{m}^{2}\right)$ was calculated by dividing weight $(\mathrm{kg})$ by height squared $\left(\mathrm{m}^{2}\right)$. According to BMI we assessed the distribution of healthy girls and girls with type 1 diabetes mellitus who were of normal weight, overweight, and obese, according to International Obesity Task Force's (IOTF) cut off points for body mass index (Cole et al., 2000).

Physical program. Two experiments were carried out. The first experiment was a 7-day physical program (7-day PP) consisting of aerobics and swimming. Aerobics and swimming sessions were held every day. The duration of these trainings was 45 minutes. At the beginning of aerobi- cs training 10 minute warming-up exercises were done, then, basic aerobics exercises were done for 30 minutes. At the end of the training participants did stretching and breathing exercises for five minutes. The aerobics trainings took place in the morning, $1-1.5$ hours after breakfast. At the beginning of the swimming training session 15 minute warming-up exercises were done, and for the remaining 30 minutes the participants swam breaststroke and on the back (up to 200 meters). Swimming sessions were held in the second part of the same day -1.5 hour after dinner. The length of the swimming pool was 25 meters. Before and after the trainings in the gymnasium and the swimming pool we measured BG level. The intensity of the trainings was always adjusted according to the participant's pulse, which was intended not to exceed $144-156$ beats / $\mathrm{min}$.

During the other experiment, which consisted of a 14-week swimming program (14-week SP), 28 training sessions were held. The participants attended swimming training sessions two times per week. One training in the swimming pool lasted for 45 minutes. Before and after the training the capillary BG level was measured. The trainings took place in a swimming pool, the length of which was 25 meters. At the beginning of the training session a 15-20-minute exercise was done, and the participants swam breaststroke and crawl for the remaining 30 minutes. At the beginning short swimming distances (up to 200 meters) with the breaks were chosen. Later the distance was increased to 400 meters with the short breaks. The intensity of the training was always adjusted according to the pulse, which we did not want to get higher than 144-156 beats / min. Trainings in the water took place in the morning, $1-1.5$ hours after breakfast.

Blood analysis. Capillary BG level was measured before every physical training session and right after it. Capillary BG level was measured by blood glucose meter "Accuchek Go" and the results were received in Systeme International (SI) unit - mmol / 1 .

Statistics. Descriptive data were presented as mean $\pm \mathrm{SD}$. To check the hypothesis of the quantitative variable, Student's t-test was used. The groups (healthy persons and diabetics) were compared with a two-way analysis of variances (ANOVA). Pearson's correlation coefficient was used for the quantitative values. Statistical significance was set at $\mathrm{p}<0.05$. 


\section{RESULTS}

The prevalence rates of normal weight, overweight, and obesity using IOTF's cut-off points for BMI (Cole et al., 2000) are presented in Table 1.

According to these findings, $31.6 \%$ of the girls with 1 type of diabetes mellitus and $89.3 \%$ of the healthy girls were of normal weight, $52.6 \%$ of the girls with 1 type of diabetes mellitus and $10.7 \%$ of the healthy girls were overweight, and only $15.8 \%$ of the girls with 1 type of diabetes mellitus were obese. The expressions of those values were the same before and after the two experiments.

A 7-day physical program in the gymnasium (aerobics) showed a statistically significant diffe- rence in BG level between healthy girls and girls with type 1 diabetes mellitus at the beginning of the experiment - before $(p<0.001)$ and after $(p<0.01)$ the first day of aerobics training. At the end of the experiment - before $(p<0.01)$ and after $(\mathrm{p}<0.05)$ the $7^{\text {th }}$ day of aerobics training a significant difference in BG level between the healthy girls and girls with type 1 diabetes mellitus was also was noticed (Table 2).

After the first day of aerobics trainings, BG level did not been vary, it decreased only by $4.5 \%$ $(p>0.05)$ for the diabetic subjects. At the end of the experiment - on the seventh day - BG concentration diminished by $8.6 \%(\mathrm{p}<0.05)$ after training. BG level for the healthy subjects was
Table 1. Distribution of healthy girls and girls with type 1 diabetes mellitus who were of normal weight, overweight, and obese, by International Obesity Task Force's (IOTF) cut off points for body mass index (BMI)

\begin{tabular}{|l|c|c|c|}
\hline \multirow{3}{*}{ Variable } & $\begin{array}{c}\text { Healthy } \\
(\mathrm{n}=28)\end{array}$ & $\begin{array}{c}\text { Type 1 diabetes mellitus } \\
(\mathrm{n}=19)\end{array}$ & $\begin{array}{c}\text { All subjects } \\
(\mathrm{n}=47)\end{array}$ \\
\cline { 2 - 4 } & $\%(\mathrm{n})$ & $\%(\mathrm{n})$ & $\%(\mathrm{n})$ \\
\hline Normal weight & $89.3 \%(25)$ & $31.6 \%(6)$ & $65.9 \%(31)$ \\
\hline Overweight & $3 \%(3)$ & $52.6 \%(10)$ & $27.7 \%(13)$ \\
\hline Obese & - & $15.8 \%(3)$ & $6.4 \%(3)$ \\
\hline
\end{tabular}

Note. Overweight and obesity was defined by IOTF (Cole et al., 2000). Normal weight: BMI $<21.20 \mathrm{~kg} / \mathrm{m}^{2}$ (females). Overweight: $21.20 \mathrm{~kg} / \mathrm{m}^{2}<\mathrm{BMI}<26.05 \mathrm{~kg} / \mathrm{m}^{2}$ (females). Obese: BMI $>26.05 \mathrm{~kg} / \mathrm{m}^{2}$ (females).

Table 2. The effect of a 7-day physical program: aerobics (AE) and swimming (SW) on the blood glucose level ( $\mathrm{mmol} / \mathrm{l}$ ) in healthy girls and girls with type 1 diabetes mellitus

Note. $p$-value - significance level between healthy girls and girls with type 1 diabetes mellitus; $p_{1}$-value - significance level within the healthy girls group and within the girls with type 1 diabetes mellitus group after the $1^{\text {st }}$ day of the experiment; $p_{2^{-}}$ value - significance level within the healthy girls group and within the girls with type 1 diabetes mellitus group after the seventh day of the experiment.

\begin{tabular}{|c|c|c|c|c|c|}
\hline & \multirow{2}{*}{\multicolumn{2}{|c|}{ Variable }} & $\begin{array}{l}\text { Healthy } \\
(\mathrm{n}=28)\end{array}$ & $\begin{array}{l}\text { Type } 1 \text { diabetes mellitus } \\
\qquad(\mathrm{n}=19)\end{array}$ & \multirow{3}{*}{$\begin{array}{c}p \text {-value } \\
p<0.001\end{array}$} \\
\hline & & & mean $\pm \mathrm{SD}$ & mean $\pm \mathrm{SD}$ & \\
\hline \multirow{3}{*}{$1^{\text {st }}$ day } & \multirow{3}{*}{$\mathrm{AE}$} & before & $5.2 \pm 0.2 \mathrm{mmol} / 1$ & $8.8 \pm 0.7 \mathrm{mmol} / 1$ & \\
\hline & & after & $4.6 \pm 0.1 \mathrm{mmol} / 1$ & $8.4 \pm 1.2 \mathrm{mmol} / 1$ & $p<0.01$ \\
\hline & & $p_{1}$-value & $p<0.01$ & $p>0.05$ & - \\
\hline \multirow{3}{*}{$7^{\text {th }}$ day } & \multirow{3}{*}{$\mathrm{AE}$} & before & $4.9 \pm 0.2 \mathrm{mmol} / 1$ & $8.1 \pm 0.8 \mathrm{mmol} / 1$ & $p<0.01$ \\
\hline & & after & $4.4 \pm 0.1 \mathrm{mmol} / 1$ & $7.4 \pm 0.9 \mathrm{mmol} / 1$ & $p<0.05$ \\
\hline & & $p_{2}$-value & $p<0.01$ & $p<0.05$ & - \\
\hline \multirow{3}{*}{$1^{\text {st }}$ day } & \multirow{3}{*}{ SW } & before & $5.2 \pm 0.1 \mathrm{mmol} / 1$ & $7.8 \pm 0.4 \mathrm{mmol} / 1$ & $p<0.001$ \\
\hline & & after & $4.8 \pm 0.1 \mathrm{mmol} / 1$ & $5.9 \pm 0.6 \mathrm{mmol} / 1$ & $p>0.05$ \\
\hline & & $p_{1}$-value & $p>0.05$ & $p<0.001$ & - \\
\hline \multirow{3}{*}{$7^{\text {th }}$ day } & \multirow{3}{*}{ SW } & before & $4.9 \pm 0.13 \mathrm{mmol} / 1$ & $6.3 \pm 0.3 \mathrm{mmol} / 1$ & $p<0.001$ \\
\hline & & after & $4.4 \pm 0.14 \mathrm{mmol} / 1$ & $4.9 \pm 0.4 \mathrm{mmol} / 1$ & $p>0.05$ \\
\hline & & $p_{2}$-value & $p<0.01$ & $p<0.001$ & - \\
\hline
\end{tabular}




\begin{tabular}{|c|c|c|c|c|c|}
\hline \multicolumn{2}{|c|}{ Variable } & $\begin{array}{l}\text { Healthy } \\
(\mathrm{n}=28)\end{array}$ & $\begin{array}{l}\text { Type } 1 \text { diabetes mellitus } \\
\qquad(\mathrm{n}=19)\end{array}$ & \multirow[t]{2}{*}{ p-value } & \multirow{8}{*}{$\begin{array}{l}\text { Table } 3 \text {. Blood glucose } \\
\text { level (mmol / } 1) \text { of the } \\
\text { healthy girls and the } \\
\text { girls with type } 1 \text { diabe- } \\
\text { tes mellitus before and } \\
\text { after the first and the } \\
28^{\text {th }} \text { swimming training } \\
\text { sessions }\end{array}$} \\
\hline \multirow{4}{*}{$\begin{array}{c}\text { First } \\
\text { swimming training } \\
\text { session }\end{array}$} & & & & & \\
\hline & before & $5.3 \pm 0.7 \mathrm{mmol} / 1$ & $9.6 \pm 0.5 \mathrm{mmol} / 1$ & $p<0.001$ & \\
\hline & after & $4.6 \pm 0.8 \mathrm{mmol} / 1$ & $6.6 \pm 0.4 \mathrm{mmol} / 1$ & $p<0.001$ & \\
\hline & $p_{1}$-value & $p<0.001$ & $p<0.001$ & - & \\
\hline \multirow{3}{*}{$\begin{array}{l}28^{\text {th }} \\
\text { swimming training } \\
\text { session }\end{array}$} & before & $4.9 \pm 0.7 \mathrm{mmol} / 1$ & $8.1 \pm 0.7 \mathrm{mmol} / 1$ & $\mathrm{p}<0.001$ & \\
\hline & after & $4.4 \pm 0.9 \mathrm{mmol} / 1$ & $5.6 \pm 0.6 \mathrm{mmol} / 1$ & $p<0.05$ & \\
\hline & $p_{2}$-value & $p<0.001$ & $p<0.001$ & - & \\
\hline
\end{tabular}

Note. $p$-value - significance level of blood glucose concentration ( $\mathrm{mmol} / \mathrm{l})$ between healthy girls and girls with type 1 diabetes mellitus; $p_{I}$-value - significance level blood glucose concentration $(\mathrm{mmol} / 1)$ within the group after the first swimming training; $p_{2}$-value - significance level blood glucose concentration (mmol/1) within the group after the $28^{\text {th }}$ swimming training.

decreased after the first day $(\mathrm{p}<0.01)$ and after the sevent hday $(\mathrm{p}<0.01)$ of aerobics training.

Comparing the $\mathrm{BG}$ concentration value before the first day of aerobics training (the beginning of the experiment) and before the seventh day of aerobics training (the end of the experiment) of type 1 diabetes mellitus subjects, we saw that BG concentration decreased by $7.9 \%$ from the initial (first training) value during a 7-day period, but this reduction was not statistically significant $(p>0.05)$. Comparing the BG concentration value after the first day of aerobics training and after the seventh day of aerobics training, a $11.9 \%$ statistically insignificant decrease from the initial (first training) value was observed during this period too $(\mathrm{p}>0.05)$. A significant decrease of BG concentration was observed comparing the BG concentration of healthy girls before the first and before the seventh day of aerobics training $(\mathrm{p}<0.001)$, but right after them the decrease of BG level value was insignificant ( $p>0.05)$.

A 7-day duration physical program in the water showed a statistically significant difference in BG level between healthy girls and the girls with type 1 diabetes mellitus at the beginning (before the first day swimming session) and at the end (before the seventh day of swimming session) of the experiment $(p<0.001)$. After the first day and after the seventh day of swimming training sessions, BG level between the healthy girls and the girls with type 1 diabetes mellitus did not vary $(\mathrm{p}>0.05)$.

On the first day, a $26.9 \%$ reduction $(p<0.001)$ in BG concentration was observed after the swimming training session for type 1 diabetes mellitus subjects. On the seventh day, a $22.2 \%$ reduction $(p<0.001)$ in BG level was noticed after the swimming training too. For the healthy subjects, after the first day of swimming training, BG level did not vary $(p>0.05)$. But after the seventh day swimming session BG level decreased $(p<0.01)$ for the healthy subjects.

Comparing the BG concentration values before the first day swimming training and before the seventh day swimming training of girls with type 1 diabetes mellitus, we found that BG concentration decreased by $19.2 \%$ from the initial (first training) value during a 7 -day period $(\mathrm{p}<0.01)$. Comparing the $\mathrm{BG}$ concentration after the first day of the physical activity in the water and after the seventh day of the physical activity in the water, a $14.0 \%$ reduction from the initial (first training) value was observed during this period but it was not statistically significant $(p>0.05)$. A significant decrease of BG concentration was observed comparing the $\mathrm{BG}$ concentration of healthy girls before the first and before the seventh day of swimming training $(\mathrm{p}<0.05)$, and right after them $(\mathrm{p}<0.001)$.

The differences in BG concentration between the healthy and diabetic groups during 14-week SP trainings (1, and 28) were statistically significant (Table 3). After the first training, the mean blood glucose concentration between the groups differed statistically significantly $(\mathrm{p}<0.001)$. BG level for girls with type 1 diabetes mellitus reduced by $31.2 \%(\mathrm{p}<0.001)$. Healthy subjects showed a statistically significant decrease in blood glucose concentration too after the first swimming training $(p<0.001)$. Comparing the change of glucose concentration between the groups during training 28 , a statistically significant difference in mean values before training $(\mathrm{p}<0.001)$ and after it $(\mathrm{p}<0.05)$ was noticed too. In the group of girls with type 1 diabetes mellitus, BG concentration was significantly reduced by $30.9 \%(\mathrm{p}<0.001)$ after training 28 in the water. In the healthy group, BG level reduced too $(\mathrm{p}<0.001)$. 


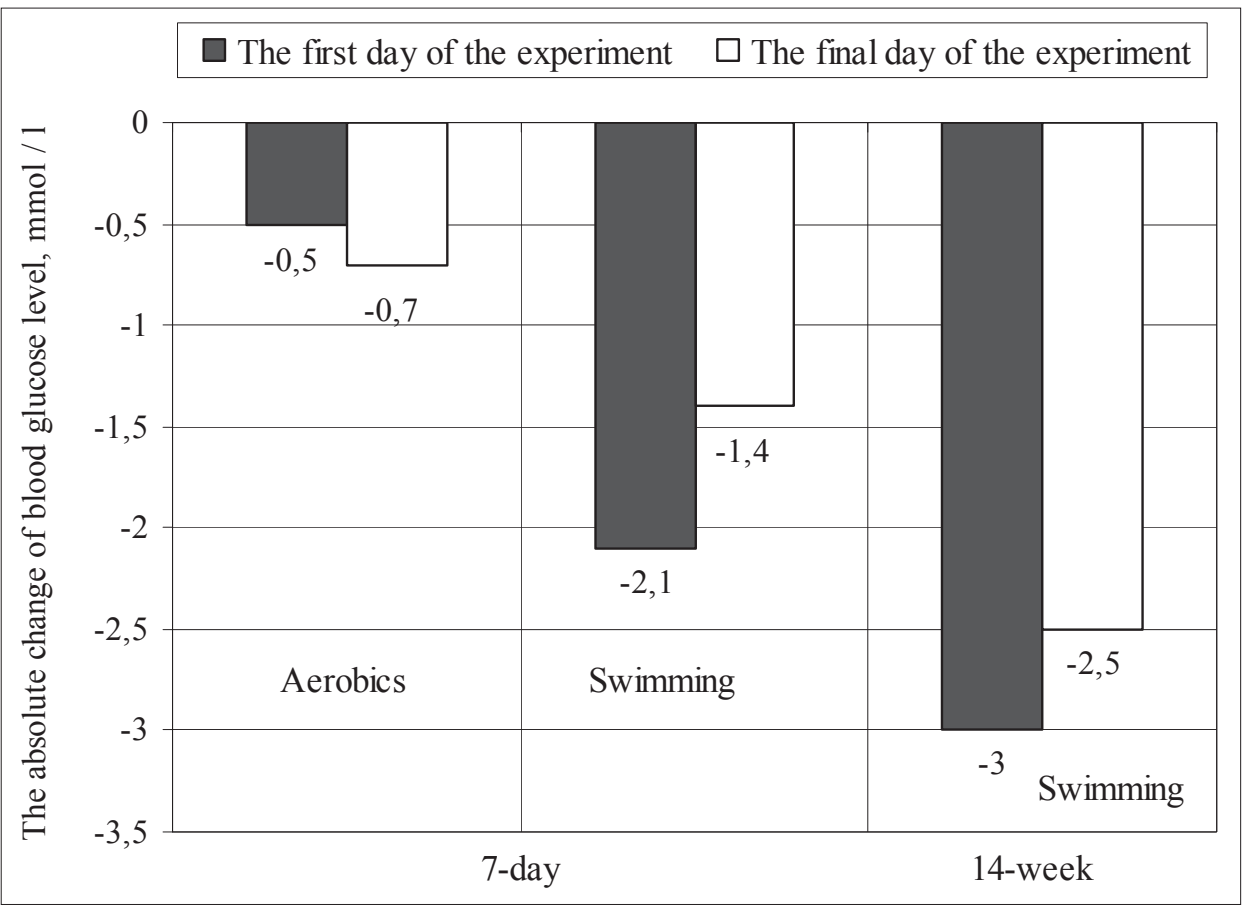

Fig. The absolute change of blood glucose level (mmol / l) of girls with type 1 diabetes mellitus before and after the 7-day physical program aerobics and swimming, and before and after the 14-week swimming program

A significant decrease of $B G$ concentration was observed comparing BG concentration before the first swimming training and before the $28^{\text {th }}$ swimming training of type 1 diabetes mellitus subjects. BG concentration decreased by $15.6 \%$ from the initial (first training) value during a 14 -week period $(p<0.05)$. Comparing the BG concentration after the first and the $28^{\text {th }}$ swimming training, $\mathrm{BG}$ level did not vary comparing it with the initial (first training) value during a 14 -week period $(p>0.05)$. A significant decrease of $\mathrm{BG}$ concentration was observed comparing the $\mathrm{BG}$ concentration of healthy girls before the first training and before the $28^{\text {th }}$ training $(\mathrm{p}<0.05)$, and right after the first trainings and the $28^{\text {th }}$ $(\mathrm{p}<0.05)$.

Regular swimming (7-day program and 14week program) reduced $\mathrm{BG}$ concentration for the girls with type 1 diabetes mellitus $(\mathrm{p}<0.001)$. The absolute change of BG level, after the first day and after the final day of the 7-day and 14week swimming was bigger than the absolute change of BG concentration after the first day and after the final day of 7-day aerobics training (Fig.).

So swimming, as one of aerobic activities, has greater effect on BG level for diabetic subjects than aerobics training.

\section{DISCUSSION}

BMI is considered one of the most appropriate measures for the indirect assessment of adiposity in adolescent (Frontini et al., 2001). In the current study the prevalence of overweight $(52.6 \%)$ and obesity (15.8\%) for girls with type 1 diabetes mellitus was found to be relatively high. The registered data are similar to those observed by the foreign scientists too - according to which, the teenage girls with type 1 diabetes mellitus subjects have a tendency for being overweight (Roldan et al., 1999; Ingberg et al., 2003; Libman et al., 2003).

Estimating the effect of regular 7-dayPP on BG concentration, aerobics and swimming training decreased BG level for all participants. Physical activity in the water had a greater impact on the dynamics of BG level for the girls with type 1 diabetes mellitus. Physical exercises improved glycemia control for girls with type 1 diabetes mellitus and for healthy girls too. So, physical exercises are useful for improving the functional state of both healthy and type 1 diabetes mellitus subjects and they decrease glucose concentration in blood (Koivisto, 1991; Maughan, Shirreffs, 1996; Foss, Keteyian, 1998; Mosher et al., 1998; Wilmore, David, 1999; Herbst et al., 2006).

BG concentration effectively decreased du- 
ring the regular 14-weekSP for all participants, but especially for diabetic girls $(p<0.001)$. In accordance with these results of our experiment, the following conclusion can be made: longterm and regular aerobic exercises effectively decrease BG level. Similar statements were also made by some other foreign scientists (Raguso et al., 1995; Temple et al., 1995; Mosher et al., 1998; Wilmore, David, 1999). Specific biochemical organism changes takes place in water: water environment limits perspiration emission, therefore, upon the presence of similar water and air temperature, in the water the human organism releases four times more of heat, oxidation processes become more intensive due to the increased heat conduction, energy input is larger (Maughan, Shirreffs, 1996; Foss, Keteyian, 1998; Maughan, Gleeson, 2004).

\section{CONCLUSIONS}

Aerobic exercises had a positive impact on the blood glucose concentration for healthy girls and girls with type 1 diabetes mellitus:

1. A 7-day physical program (aerobics and swimming trainings) decreased blood glucose concentration for all participants. However, physical activity in the water decreased blood glucose concentration for type 1 diabetes mellitus subjects more significantly than aerobics.

2. A 14-week swimming program decreased blood glucose concentration, but a marked change of this dimension was observed for the girls with type 1 diabetes mellitus. So, both aerobic exercises - swimming and aerobics - reduced blood glucose concentration, but a marked change of this index was observed after the physical activity in the water.

\section{REFERENCES}

Bhaskarabhatla, K. V., Birrer, R. (2005). Physical activity and diabetes mellitus. Comprehensive Therapy, 31 (4), $291-298$

Bernardini, A. L., Vanelli, M., Chiari, G. et al. (2004). Adherence to physical activity in young people with type 1 diabetes. Acta Bio-medica de L'Ateneo Parmense, 75 (3), 153-157.

Cole, T. J., Bellizzi, M. C., Flegal, K. M., Dietz, W. H. (2000). Establishing a standard definition for child overweight and obesity worldwide: International survey. British Medical Journal, 320, 1240-1243.

Defrin, R., Josefsberg, Z., Karp, M. (2004). The effect of acute physical activity on blood glucose levels of children with insulin-dependent diabetes mellitus. Harefuah, 143 (12), 856-860, 911, 912 .

Foss, M., Keteyian, S. J. (1998). Physiological Basis for Exercise and Sport. Boston: McGraw-Hill.

Frontini, M. G., Bao, W., Elkasabny A., Srinivasan S. R., Berenson, G. (2001). Comparison of weight-for-height indices as a measure of adiposity and cardiovascular risk from childhood to young adulthood: the Bogalusa heart study. Journal of Clinical Epidemiology, 54, 817-822.

Herbst, A., Bachran, R., Kapellen, T., Holl, R. W. (2006). Effects of regular physical activity on control of glycemia in pediatric patients with type 1 diabetes mellitus. Archives of Pediatrics and Adolescent Medicine, 160 (6), $573-577$.

Ingberg, C. M., Sarnblad, S., Palmer, M. et al. (2003). Body composition in adolescent girls with type I diabetes. Diabetes Medicine, 20 (12), 1005-1011.

Koivisto, A. V. (1991). Exercise and Diabetes Mellitus. Textbook of Diabetes, Vol. 2, 78, 795-801.

Libman, I. M., Pietropaolo, M., Arslanian, S. A., LaPorte, R. E., Becker, D. J. (2003). Changing prevalence of overweight children and adolescents at onset of insulintreated diabetes. Diabetes Care, 26 (10), 2871-2875.

Lohman, T., Roche, A., Mastorell, R. (1991). Anthropometric Standardization Reference Manual. Champaign, IL: Human Kinetics.

Maughan, R., Gleeson, M. (2004). The Biochemical Basis of Sports Performance. Oxford: Oxford University Press.

Maughan, R., Shirreffs, S. M. (1996). Biochemistry of Exercise IX. Champaign, IL: Human Kinetics.

Mosher, P. E., Nash, M. S., Perry, A. C., LaPerriere, A. R., Goldberg, R. B. (1998). Aerobic circuit exercise training: effect on adolescents with well-controlled insulin-dependent diabetes mellitus. Archives of Physical Medicine and Rehabilitation, 79 (6), 652-657.

Raguso, C. A., Coggan, A. R., Gastaldelli, A. et al. (1995). Lipid and carbohydrate metabolism in IDDM during moderate and intense exercise. Diabetes, 44 (9), $1066-1074$

Riddell, M., Iscoe, K. (2006). Physical activity, sport, and pediatric diabetes. Pediatric Diabetes, 7 (1), 60-70.

Roldan Martin, M. B., Escobar-Morreale, H., Alonso Blanco, M., Barrio Castellanos, R. (1999). Pubertal growth, final height and weight gain in girls diagnosed with IDDM during pre-pubertal period. Anales Espanoles de Pediatria, 51 (5), 493-498.

Temple, M. Y., Bar-Or, O., Riddell, M. C. (1995). The reliability and repeatability of the blood glucose response to prolonged exercise in adolescent boys with IDDM. Diabetes Care, 18 (3), 326-332.

The Diabetes Research in Children Network (DirecNet) Study Group. (2006). The effects of aerobic exercise on glucose and counterregulatory hormone concentrations in children with type 1 diabetes. Diabetes Care, 29, 20-25. Wilmore, J. H., David, L. C. (1999). Physiology of Sport and Eexercise. Champaign, IL: Human Kinetics. 


\title{
AEROBINIŲ PRATIMŲ POVEIKIS SVEIKŲ IR SERGANČIŲ 1 TIPO CUKRINIU DIABETU MERGINŲ KRAUJO GLIUKOZĖS KONCENTRACIJAI
}

\author{
Sandrija Sideravičiūtė, Alina Gailiūnienė, Kristina Visagurskienė, Daiva Vizbaraitė \\ Lietuvos kūno kultūros akademija, Kaunas, Lietuva
}

\begin{abstract}
SANTRAUKA
Reguliarūs aerobinio pobūdžio fiziniai pratimai naudingi ne tik sveikiems žmonėms. Fizinis aktyvumas yra labai svarbi gyvenimo dalis vaikams ir jauniems žmonèms, sergantiems 1 tipo cukriniu diabetu. Vaikščiojimas, plaukimas, važinėjimas dviračiu, šokiai ir daugelis kitų fizinio aktyvumo formų, dar vadinamu aerobiniais pratimais, yra naudingos žmogaus sveikatai. Kyla klausimas, kokie fiziniai pratimai yra naudingiausi jauniems žmonėms, sergantiems 1 tipo cukriniu diabetu?

Tyrimo tikslas - ivertinti ir palyginti, kaip aerobinio pobūdžio pratimai (plaukimas ir aerobika) veikia jaunų merginų kraujo gliukozės koncentraciją. Buvo tiriama 19 merginų, sergančiu 1 tipo cukriniu diabetu (amžius - 16,5 $\pm 0,24$ m., ligos trukmé $-8,1 \pm 0,9 \mathrm{~m}$.), ir 28 sveikos merginos (amžiaus vidurkis — $16,9 \pm 0,36 \mathrm{~m}$.).

Buvo atlikti du eksperimentai. Pirmas eksperimentas — tai septynių dienų trukmės fizinè programa, kurią sudare aerobikos bei plaukimo treniruotès, vykdomos kiekvieną dieną. Kito eksperimento metu pratybos buvo vykdomos tik vandenyje. Jie vyko 14 savaičiu ( 28 pratybos), dukart per savaitę, trukmè -45 min. Krūvio intensyvumas buvo koreguojamas matuojant pulsą (144-156 tv. / min). Kraujo gliukozès koncentracija matuojama prieš ir iškart po kiekvienų septynių dienų trukmės pratybų bei 14 savaičių trukmės fizinių programų metu.

Septynių dienų trukmès fizinè programa sumažino visų tiriamujų kraujo gliukozès koncentraciją $(\mathrm{p}<0.05)$, bet plaukimo pratybos turèjo didesni poveikị sergančiu 1 tipo cukriniu diabetu merginų kraujo gliukozès koncentracijos mažèjimui nei aerobikos pratybos. Po 14 savaičių trukmès plaukimo programos reikšmingai sumažèjo visų tiriamujų kraujo gliukozės koncentracija, tačiau sergančių 1 tipo cukriniu diabetu merginu glikemijos reakcija į fizinị krūvị vandenyje buvo didesnè $(\mathrm{p}<0,001)$.

Gauti rezultatai parodè, kad plaukimas ir aerobika sumažina sveikų ir sergančių 1 tipo cukriniu diabetu merginų kraujo gliukozės koncentraciją. Visgi pratybos vandenyje lèmė didesni sergančių 1 tipo cukriniu diabetu merginų šio rodmens kitimą nei aerobikos pratybos.
\end{abstract}

Raktažodžiai: 1 tipo cukrinis diabetes, plaukimas, aerobika, kraujo gliukozė, glikemija.

\author{
Lietuvos kūno kultūros akademija \\ (Lithuanian Academy of Physical Education) \\ Sporto str. 6, LT-44221 Kaunas \\ Lietuva (Lithuania) \\ Tel +370 37302671 \\ E-mail sideraviciute@1kka.1t
}

